\section{CLADOCERA (CRUSTACEA) OF TAMIL NADU - CHECKLIST AND BIBLIOGRAPHY}

\author{
M.B. Raghunathan and R. Suresh Kumar
}

Zoological Survey of India, Southern Regional Station, 100 Santhome Road, Chennai, Tamil Nadu 600028, India.

Cladoceran investigation of Tamil Nadu was initiated by Rajagopal (1962) with recordings from Madras coastal waters. Seasonal events in a natural population of Daphnia carinata were studied by Vijayaraghavan (1970). Navaneethakrishnan and Michael (1971) investigated the egg production and relative growth in Daphnia carinata. Vijayalakshmi and Venugopalan (1972) investigated the biological aspects of Penilia avirostris in Portonovo waters. Murugan and Sivaramakrishnan (1973) studied the biology of Simocephalus acutriostratus. Further Michael (1973) made a detailed analysis of the cladocerans of Madurai area. Murugan (1975a,b) made biological studies of Moina micrura and Ceriodaphnia cornuta. Santhanam et al. (1975) studied the zooplankton of Portonovo waters, Kaliyamurthy (1975) investigated the plankton of Pulicat Lake. Murugan and Sivaramakrishnan (1976) carried out laboratory studies on Scapholeberis kingi. Murugan and Venkataraman (1977) studied the developmental aspects of Daphnia carinata. Murugan and Ramaseshan (1978) studied Scapholeberis kingi and production of ephippia. Santharam (1978) studied the biology of Daphnia carinata. Venkataraman and Job (1980) made further studies on the effect of temperature on the growth of Daphnia carinata. Raghunathan (1983) reported the planktonic Cladocera of Tamil Nadu. Raghunathan and Srinivasan (1983a,b) investigated the cladocerans of Ennore Estuary. Further Raghunathan and Srinivasan (1986) have worked on the zooplankton dynamics in relation to hydrographic features of Ennore Estuary. Venkataraman (1983) worked out the taxonomy and ecology of Cladocera of southern Tamil Nadu, Venkataraman and Krishnaswamy (1984a,b) reported the occurrence of Leydigia ciliata and Daphnia from Tamil Nadu. Venkataraman and Krishnaswamy (1985) further studied the cultural aspects of Diaphanosoma senegal. Cladocerans from high altitude waters of Tamil Nadu were studied by Raghunathan (1985). The same author investigated the Cladocerans of certain urban water bodies in 1986. Studies pertaining to predation of Anisops bouveri on Daphnia cephalata were made by Venkataraman and Krishnaswamy (1986). Manimegalai et al. (1986) studied the helmet development in Daphnia cephalata. Hudec (1987) described a new species, Moina oryzae from Tamil
Nadu. Michael and Sharma (1988) have completed the Fauna of India volume on Cladocera. Raghunathan (1989) reviewed the work on Indian Cladocera. Raghunathan (1990, 1991, 1992, 1995) conducted ecological studies on the cladoceran fauna of different ponds in Tamil Nadu. Raghunathan and Revathy (1999a,b,c) made studies on the cladoceran species associations, reproduction and on the natural population of a village pond. Suresh Kumar et al. (1999) recorded a chydorid cladoceran, Pleuroxus aduncus Jurine and its developmental stages from Tamil Nadu. Venkataraman (1999) reported the Cladocera of southern Tamil Nadu. Sureshkumar (2000) carried out a detailed analysis of Cladocera of Tamil Nadu and their possible utilization in aquaculture and Sivakumar et al. (2001) made a study on the Cladocera of Dharmapuri District.

For the first time a comprehensive and consolidated list of Cladocera of Tamil Nadu is presented 81 species of cladocerans are recorded from Tamil Nadu with major representation from family Chydoridae (40) and Daphniidae (17) (Table 1). Compared with other states, in India this group has been fairly well studied in Tamil Nadu.

Studies have also been conducted to mass culture cladocerans for ascertaining their suitability as alternative live food in aquaculture. In this connection, studies were made pertaining to Monia micrura., Ceriodaphnia cornuta, Daphnia carinata, Simocephalus vetulus, Daphnia cephalata, Daphnia lumholtzi and Macrothrix spinosa for culture purposes. In natural situations monoculture like stages (swarming) have also been observed earlier by Raghunathan $(1983,1992)$.

\section{Acknowledgements}

The authors are thankful to the Director, Zoological Survey of India, Kolkata and the Officer-in-Charge, Southern Regional Station, Zoological Survey of India, Chennai for encouragement and facilities.

\section{References}

Hudec, I. (1987). Moina oryzae n. sp. (Cladocera: Moinidae) from Tamilnadu (South India). Hydrobiologia 145: 147-150.

Kaliyamurthy, M. (1975). Observations on the plankton ecology of Pulicat lake. Indian Journal of Fisheries 22: 86-94.

Manimeghalai, S., K. Venkatraman and S. Krishnaswamy (1986). Helmet development in Daphnia cephalata King under laboratory conditions. Current Science 55: 930-931.

Michael, R.G. (1973). Cladocera. A guide to the study of freshwater organisms. Journal of Madurai University (Supplement) 1: 71-85

Michael, R.G. and B.K. Sharma (1988). Indian Cladocera. Fauna of India. Zoological Survey of India, Calcutta.

Murugan, N. and K.G. Sivaramakrishnan (1973). The biology of Simocephalus acutirostratus King (Cladocera: Daphniidae). Laboratory studies of life span, instar duration, egg production, growth and stages in embryonic development. Freshwater Biology 3: 77-83

Murugan, N. and K.G. Sivaramakrishnan (1976). Laboratory studies on the longevity, instar duration, growth, reproduction and embryonic development in Scapholeberis kingi Sarss, 1903. Cladocera. 
Table 1. Systematic list of Cladocera of Tamil Nadu

\begin{tabular}{|c|c|c|}
\hline Scientific name & Scientific name & Scientific name \\
\hline Sididae & Moina macrocopa (Straus) & Dunhevedia crassa crassa King \\
\hline Pseudosida bidentata Herrick & Moina brachiata (Jurine) & Dunhevedia serrata Daday \\
\hline Pseudosida szalayi Daday & Moina weismannilshikawa & Dadaya macrops (Daday) \\
\hline Sida crystallina (O.F. Muller) & Moina oryzae Hudec & Pseudochydorus globosus (Baird) \\
\hline Latanopsis australis Sars & Moinadaphnia macleayi (King) & Alona quadrangularis (O.F. Muller) \\
\hline Diaphanosoma excisum Sars & & Alona rectangula rectangula Sars \\
\hline Diaphanosoma sarsi Richard & Bosminidae & Alona davidi davidi Richard \\
\hline Diaphanosoma senegal Gauthier & Bosmina longirostris (O.F.Muller) & Alona davidi punctata (Daday) \\
\hline Diaphanosoma brachyuram (Lieven) & Bosminopsis deitersi Richard & Alona costata Sars \\
\hline \multirow[t]{2}{*}{ Penilia avirostris Dama } & & Alona monocantha tridetata (Stingelin) \\
\hline & Macrothricidae & Alona pulchella King \\
\hline Daphniidae & Macrothrix spinosa King & Alona guttata Sars \\
\hline Ceriodaphnia cornuta Sars & Macrothrix laticornis (Jurine) & Alona cf. karelica Stenroos \\
\hline Ceriodaphnia quadrangula (O.F. Muller) & Guernella raphalis Richard & Alona sarsinorum Stingelin \\
\hline Ceriodaphnia laticaudata P.E. Muller & Grimaldina brazzai (Richard). & Alona cannellata Brehm \\
\hline Ceriodaphnia pulchella Sars & & Alona pseudonodonta anodonta Daday \\
\hline Daphnia carinata King & Ilyocryptidae & Graptoleberis testudinaria (Fischer) \\
\hline Daphnia cephalata (King) & liyocryptes spinifer Herrick & Leydigia acanthocercoides (Fischer) \\
\hline Daphnia lumholtzi Sars & & Leydigia australis ceylonica (Daday) \\
\hline Daphnia longicephala Hebert & $\underline{\text { Chydoridae }}$ & Leydigia ciliata (Gauthier) \\
\hline Daphnia similis Claus & $\overline{\text { Pleuroxus aduncus (Jurine) }}$ & Biapertura karua (King) \\
\hline Daphnia projecta Hebert & Alonella nana (Baird) & Biapertura verrucosa (Sars) \\
\hline Scapholeberis kingi Sars & Chydorus sphaericus (O.F. Muller) & Oxyurella singalensis (Daday) \\
\hline Simocephalus vetulus (O.F. Muller) & Chydorus parvus (Daday) & Kurzia longirostris (Daday) \\
\hline Simocephalus vetuloides Sars & Chydorus cf. herrmanni & Euryalona orientalis (Daday) \\
\hline Simocephalus exspinosus (Koch) & Chydorus kallipygos Brehm & Indialona globulosa (Daday) \\
\hline Simocephalus latirostris Stingelin & Chydorus barroisi Richard & Notalona globulosa (Daday) \\
\hline Simocephalus acutirostratus (King) & Chydorus ventricosus Daday & Ephemeroporus barroisi Richard \\
\hline \multirow[t]{2}{*}{ Simocephaius serrulatus (Koch). } & Chydorus reticulatus Daday & \\
\hline & Chydorus eurynotus Sars & $\underline{\text { Podonidae }}$ \\
\hline Moinidae & Chydorus robustus Stingelin & Evadne tergestina Claus \\
\hline Moina micrura Kurz & Chydorus brehmi Biswas & Podon polyphemoides (Leuckart) \\
\hline
\end{tabular}

Hydrobiologia, 50.75-80.

Murugan, N. (1975a). Egg production, development and growth in Moina micrura Kurz 1874 (Cladocera: Moinidae). Freshwater Biology 5: 245-250.

Murugan, N. (1975b). The biology of Ceriodaphnia cornuta Sars. Journal of Inland Fisheries Society of India 7: 80-87.

Murugan, N. and S. Ramaseshan (1978). Observations on the production of resting eggs (ephippia) in the epineustic Cladoceran Scapholeberis kingi Sars (1903) (Cladocera: Daphniidae)

Murugan, N. and K. Venkataraman (1977). Study of the in vitro development of parthenogenetic egg of Daphnia carinata King (Cladocera: Daphniidae). Hydrobiologica 52: 129-134.

Navaneethakrishnan, H. and R.G. Michael (1971). Egg production and growth in Daphnia carinata King. Proceedings of the Indian Academy of Science (Animal Science) 73: 117-123.

Raghunathan, M.B. (1983). Studies on some planktonic Cladocera of Tamil Nadu. Ph.D. Thesis. Madras University.

Raghunathan, M.B. (1985). Studies on freshwater Cladocera of Tamil Nadu. 3. High altitude waters. Proceedings of National Symposium on
Pure and Applied Limnology. Bulletin of Botanical Society, Sagar 6063.

Raghunathan, M.B. (1986). Cladocera (Crustacea) of certain urban water bodies. All India Seminar on water quality around urban ecosystems and management, Chindwara. Proceedings Pp. 5-8.

Raghunathan, M.B. (1989). Indian Cladocera (Crustacea). Indian Review of Life Sciences 9: 137-152.

Raghunathan, M.B. (1990). Seasonal studies on freshwater Cladocera of Chingleput Tank, Tamil Nadu. Records of the Zoological Survey of India 86(2): 253-259.

Raghunathan, M.B. (1991). Cladoceran investigations in a pond with macrophytes and algal blooms. Records of the Zoological Survey of India 88(1): 81-85.

Raghunathan, M.B. (1992). Events in a natural population of Daphnia lumholtzi Sars (Crustacea: Cladocera). Records of the Zoological Survey of India 91(2): 185-188.

Raghunathan, M.B. (1995). Studies on certain tank ecosystems in Tamil Nadu India. In: Timotius, K.H. and F. Goltenboth (editors). Tropical Limnology. Vol. II. Satyawacana University Press, Salatiga, 
Indonesia.

Raghunathan, M.B. and K. Revathi (1999a). Planktonic Cladocera (Crustacea) and species associations, pp. 167-172. In: K. Vijayakumar (editor). Freshwater Ecosystem of India. Daya Publishing House, New Delhi.

Raghunathan, M.B. and K. Revathi (1999b). Some aspects of reproduction in Cladocera (Crustacea). Journal of Experimental Zoology India 2(1): 81-83.

Raghunathan, M.B. and K. Revathi (1999c). Limnological studies of a village pond in Tamil Nadu, pp. 160-166. In: K. Vijayakumar (editor). Freshwater Ecosystem of India. Daya Publishing House, New Delhi.

Raghunathan, M.B. and M. Srinivasan (1983a). Cladocerans of the planktonic community in Ennore Estuary, Madras. Bulletin of Zoological Survey of India 5: 41-46.

Raghunathan, M.B. and M. Srinivasan (1983b). Zooplankton dynamics and hydrographic features of Ennore Estuary, Madras. Records of the Zoological Survey of India Occasional Paper 40: 1-30.

Rajagopal, P.K. (1962). Notes on the occurrence of Cladocera in the Madras coastal waters. Current Science 31: 467-468.

Santhanam, R., K. Krishnamurthy and R.C. Subbaraju (1975). Zooplankton of Portonovo, South India. Bulletin of the Department of Marine Science, University of Cochin, 7: 899-911.

Santharam, K.R. (1978). Biology of Daphnia carinata King. Ph.D. Thesis. Madurai Kamaraj University.

Sivakumar, K., P. Sujatha and K. Altaff (2001). Studies on the freshwater copepods and Cladocera of Dharmapuri District, Tamilnadu. Journal of Aquatic Biology 16(1\&2):5-10.

Sureshkumar, R. (2000). Studies on freshwater cladocerans for use as live feed in Aquaculture. Ph.D Thesis, Madras University, 148pp. Sureshkumar, R., K. Altaff and M.B. Raghunathan (1999). New record of a chydorid cladoceran, Pleuroxus aduncus Jurine (1820) from Chennai, south India with the description of the developmental stages. Journal of Aquatic Biology 14(1\&2): 7-10.
Venkataraman, K. (1983). Taxonomy and ecology of Cladocera of southern Tamilnadu. Ph.D. Thesis. Madurai Kamaraj University, Madurai.

Venkataraman, K. (1999). Freshwater Cladocera (Crustacea) of southern Tamilnadu. Journal of the Bombay Natural History Society 96(2): 268-280.

Venkataraman, K. and S.V. Job (1980). Effect of temperature on the development, growth and egg production in Daphnia carinata King (Cladocera: Daphniidae). Hydrobiologia 68: 217- 224.

Venkataraman, K. and S. Krishnaswamy (1984a). On the occurrence of Daphnia projecta Herbert, 1977 (Cladocera: Daphniidae) and description of male from southern Tamil Nadu, Current Science 53: 591-592.

Venkataraman, K. and S. Krishnaswamy (1984b). On the occurrence of Leydigia cilia Gauthier (Cladocera: Chydoridae) from south India. Current Science 53: 1097-1098.

Venkataraman, K. and S. Krishnaswamy (1985). Laboratory culture of Diaphanosoma senegal Gauthier (Crustacea: Cladocera) from south India. Proceedings of the Indian Academy of Science (Animal Science) 94: 87-91.

Venkataraman, K. and S. Krishnaswamy (1986). Anisops bouveri predation and advantages of cephalic expansion in Daphnia cephalata King and the impact of predation on Daphnia cephalata King and the impact of predation on Daphnia similes Claus under laboratory conditions. Proceedings of the Indian Academy of Science (Animal Science) 95: 509-513.

Vijayalakshmi, G.S. and V.K. Venugopalan (1972). Occurrence and fertility of Penilia avirostris Dana (Cladocera) in Portonovo waters. Indian. Journal of Marine Science 1(2): 125-130.

Vijayaraghavan, S. (1970). Seasonal events in a natural population of Daphnia carinata King Proceedings of the Indian Academy of Science (Animal Science) 94: 87-91. 